\title{
PERAN GENDER DALAM BUDAYA JAWA
}

\author{
Qurotul Uyun \\ Universitas Islam Indonesia
}

\begin{abstract}
Abstrak
Tulisan ini bermaksud untuk membahas peran genderdalam berbagai budaya, khususnya budaya Jaws. Perbedaan peran gender antara lakilakl dan perempuan ada dalam semua budaya. Banyak stereotip yang muncul secara universal mengenai perbedaan gendersecara lintas budaya seperti agresivitas, kekuatan, dan kurang emosional pada laki-laki, s9rta kelemahan, penerimaan dan emosionalitas pada perempuan. Kotimpangan peran gender antara perempuan dan laki-laki dalam budaya Jawa telah mengalami perubahan, tetapi ternya ta masih ada subordinasi terhadap persmpuan. Anggapan tersebut didukung oleh penelitian yang dilakukan d Surakarta sebagai representasi budaya Jawapnayi, sertapenelitian yang dilakukandi desa Limbangan, Katon yangmewakili masyarakai Jawapedesaan Hasithasil penelitian tersebut menggambarkan bahwa pergeseran pandangan mengenal peran gendersudah ada, seperti dalam masyarakat prayi maupun masyarakaldesa yang sudah banyak menerima pendidikan, tatapi tidak menjadikan kedudukan perempuan menjadiseimbang tehadap laki-laki. Faktor sosial dan budaya Jawa lelah mengakar, sehingga pandangan orang tehadap peran gender tidak mudah untuk berubah. $\mathrm{Ha}$ itu memerukan pemikiran lebih lanjut untuk mengurangi ketimpangan peran gender di masyarakal dengan pemahaman terhadap budaya.
\end{abstract}

Kata-kata Kunci: Pe ran gender, budaya Jawa.

\section{PENDAHULUAN}

$\mathbf{P}$ erlakuan diskriminatif terhadap perempuan dari masa ke masa semakin kompleks, meskipun gerakan kesadaran genderbanyak digalakkan. Kasus ketidakadlan genderdi masyarakat menyenuakdalam berbagai bentuk, dari pengasuhan anak, hubungan suami - isteri, gaji yang berbeda, pelecehan seksual, pemerkosaan, sampai dalam dunia politik dan pendidikan yang kesemuanya menempatkan perempuan pada posisi lebih rendah daripada laki-laki.

Perlakuan tidak adil tersebut semakin dirasakan perempuan. Beban hidup perempuan lebih berat daripada laki-laki. Data yang mengungkapkan kegiatan keluarga harian menunjukkan beban yang dipikul oleh perempuan lebih berat dibandingkan dengan laki-laki, digambarkan pada tabel 1. Tabel tersebut mengungkapkan secara tegas gambaran mengenai perempuan petani, namun dapat diprediksikan bahwa ada perbedaan jumlah waktu istirahat antara laki-laki dan perempuan di masyarakat. Lakilaki memiliki leblh banyak waktu untuk dirinya sendiri maupun untuk beristirahat. Perempuan lebih banyak menghabiskan waktunya untuk keluarga. 
Tabel 1

Jadwal Kegiatan Keluarga Harian

\begin{tabular}{|c|c|c|}
\hline Jam & Perempuan & Laki- Laki \\
\hline 04,00 & $\begin{array}{l}\text { 1. Bangun pagi } \\
\text { 2. Masak air } \\
\text { 3. Cuci piring dan sebagainya. }\end{array}$ & Masih istirahat (tidur) \\
\hline 05.00 & $\begin{array}{l}\text { 4. Shalat Shubuh } \\
\text { 5. Masak nasl }\end{array}$ & 1. Shalat Shubuh \\
\hline 06,00 & $\begin{array}{l}\text { 6. Membersihkan rumah } \\
\text { 7. Mencuci pakaian }\end{array}$ & 2. Istirahat (minum kopi dan merokok) \\
\hline 07.00 & 8. Mengurus anak & 3. Menyiapkan perlengkapan kerja \\
\hline $\begin{array}{l}08.00 \\
09.00 \\
10.00\end{array}$ & $\begin{array}{l}\text { 9. Kerja di sawah bersama suami atau kerja di } \\
\text { kebun, atau menggantikan suami kerja d } \\
\text { ladang orang lain. }\end{array}$ & $\begin{array}{l}\text { 4. Kerja d sawah sendiri atau di sawah } \\
\text { orang lain. }\end{array}$ \\
\hline 11.00 & 10. Menyiapkan makan siang & \\
\hline 12.00 & $\begin{array}{l}\text { 11. Mengantar makan ke sawah atau makan d } \\
\text { rumah }\end{array}$ & 5. Makan siang \\
\hline 13.00 & 12. Shalat Dhuhur & 6. Shadat Dhuhur \\
\hline $\begin{array}{l}14.00 \\
15.00 \\
16.00\end{array}$ & 13. Mengasuh anak & $\begin{array}{l}\text { 7. Istirahat (tidur) } \\
\text { 8. Kembali kg sawah / ladang }\end{array}$ \\
\hline 17.00 & $\begin{array}{l}\text { 14. Shalat Ashar } \\
\text { 15. Bersih-bersih } \\
\text { 16. Memandikan anak }\end{array}$ & $\begin{array}{l}\text { 9. Shalat Ashar } \\
\text { 10. Istiraha! } \\
\text { 11. Membantu mengasuh anak }\end{array}$ \\
\hline 18.00 & $\begin{array}{l}\text { 17. Menyiapkan makan malam } \\
\text { 18. Mencuci pring, dan sebagainya } \\
\text { 19. Shalat Maghrib }\end{array}$ & $\begin{array}{l}\text { 12. Membantu mengasuh anak } \\
\text { 13. Shafat Maghrib }\end{array}$ \\
\hline 79.00 & $\begin{array}{l}\text { 20. Makan malam } \\
\text { 21. Shalat isya }\end{array}$ & $\begin{array}{l}\text { 14. Makan malam } \\
\text { 15. Shalat sya } \\
\text { 16. Menemani anak beiajar }\end{array}$ \\
\hline $\begin{array}{l}20.00 \\
21.00 \\
22.00\end{array}$ & $\begin{array}{l}\text { 22. Mengasuh anak } \\
\text { 23. Menidurkan anak } \\
\text { 24. Istirahat }\end{array}$ & 17. Istirahat (tidur) \\
\hline
\end{tabular}

Data primer 1998 (Jurnal Perempuan Edisi 11, Mei-Juli, 1999, hai 20 dalam Ervita, 2000)

Pekejaan rumahtangga, bag perempuan di seluruh dunia merupakan bagian penting dari peran gendemya. Peran gender (gender role) tersebut merupakan aktivitas tempat mereka, khususnya jika telah memiliki anak, harus mencurahkan energi dan komitmennya pada keluarga (Mosse, 1996). Komitmen perempuan terhadap keluarga yang begitu tinggi sering kali menimbulkan perasaan bersalahjika hans "meninggalkan" tugasnya di rumah, apalagi bagi perempuan yang bekerja di iuar rumah. Akibatnya perempuan dituntut untuk menanggung beban ganda. Perempuan seringkali harus mengerjakan tugas di luar rumah sekaligus mengerjakan rumah tangga, seperti: memasak, mencuci, mengasuh anak, dan melayani suami. Gambaran tersebut menunjukkan bahwa ada tuntutanyang tidak seimbang terhadap perempuan dan laki-laki, sehingga menyebabkan ketidaksetaraan peran gender. 
Salah satı faktor yang membentuk peran gender adalah faktor sosio kultural. Budaya mempengaruhi perilaku yang berhubungan dengan seks dan gender. Bayi yang baru saja dilahirkan mempunyai seks, tetapl tidak mempunyai gender. Gender adalah suatu konstruk yang berkembang o masa kanak-kanak yang disosialisasikan dalam lingkungan mereka. Anak-anak akan mempelajari periaku spesifik dan pola perilaku yang sesuai dan tidak sesuai dengan jenis kelamin mereka, sehingga memunculkan perbedaan perilak $\downarrow$ (Matsumoto, 1996).

Hasil penelitian yang sangat terkenal telah dilakukan oleh Hofstede (Matsumoto, 1996), mengungkapkan bahwa salah satu dari empat dimensi budaya disebut masculinity(MA). Dimensi íni berhubungan dengan seberapa besar budaya akan mendukung. mendorong, memelihara perbedaan antara laki-laki dan perempuan.

Budaya yang mempunyai skor tinggi pada MA cenderung menganggap perbedaan yang jelas antara perempuan dan lakilaki. Budaya yang memiliki MA rendah meminimalkan perbedaan antar jenis kelamin dan gender. Misalnya Orang Indonesia disebutkan dalam penelitian Hofstede menduduki rangking ke-30 pada dimensi MA, maka menınjukkan perbedaan peran gender yang cukup tinggi (Munro, et. al, 1997). Sedangkan orang Amerika cenderung mempunyai MA yang rendah, maka mereka cenderung tidak terlalı membedakan perilakı berdasarkan gender. Hal tersebut didukung oleh penelitian Chang (1999) yang menghasilkan bahwa orang Amerika dari Florida dan Michigan lebih egallterterhadap peran gender dbandingkan dengan orang Cina dari Hongkong dan Bejijing. Jad;, dapat dikatakan bahwa pembagian perilaku atau sifat berdasarkan jenls kelamin ada pada semua budaya, tetapl masing-masing budaya akan berbeda intensitasnya. Dengan demikian perlu diketahui seberapa besar sistem budaya tertent $u$ berpengaruh dalam menentukan perilaku yang berkaitan dengan jenis kelamin.

Indonesia terkenal dengan berbagai suku bangsa yang mencirikan kebudayaan tertentu. Darwin dan Tukiran (2001) menyebutkan bahwa keseluruhan masyarakat Indonesia adalah masyarakat patriarkhls, meskipun kemajuan sudah tercapai. Sistem patriarkhis o Indonesia menggejala, baik pada masyarakat yang menganut sistem patrilineal (misainya Batak), bilateral (misalnya Jawa), maupun matrilineal (misalnya Minang). Sistem patriarkhis menganggap bahwa kedudukan laki-laki lebih tinggi dibandingkan dengan perempuan.

Budaya patriarkhis juga menyebabkan subordinasi terhadap perempuan semakin subur. Hal tersebut ditegaskan oleh Umar (1999) bahwa persoalan gender berpotensi untuk menimbulkan konflik dan perubahan sosial, karena sistem patriarkhis yang berkembang luas dalam berbagai masyarakat menempatkan perempuan pada posisi yang tidak diuntungkan secara kultıral, struktural, dan ekologis. Kedudukan laki-laki dalam sistem patriarki sosial dianggap lebih tinggi daripada kedudukan perempluan. Perempuan dipojokkan ke dalam urusan-urusan reproduksi seperti menjaga rumah dan mengasuh anak.

Budaya Jawa sering disebut-sebut sebagai budaya yang sangat patriarkhis, seperti diuraikan dalam sejarah Jawa bahwa wanita Jawa abad 18 dalam tradisi dah pemerintahan kerajaan Jawa didapati gambaran tentang eksistensi mereka yang tidak lebih dari sekedar kanca wingking (Fananle, 2000). MasyarakatJawa abad 18 masth mendudukan wanita dalam posisl inferior, namun dalam perkembahgah lebih lanjut juga dlsebutkan bahwa sistem kerajaan tidak ingin menjadikan perbedaan antara wanita dan pria sebagai penghalang terciptanya suatu bentuk kerja sama yang 
kuat. Perbedaan antara kedua jenis kelamin tersebut bukan unsur-unsur yang harus dipertentangkan, tetapi sebagai kekuatan yang saling melengkapi dan memungkinkan terbentuknya hubungan serasi dalam rangka membangun masyarakat yang sakiyeg sakeka kapfi (manusia yang mempunyai kesamaan tanggung jawab).

Jaman sekarang tampak peran wanita sudah cukup besar dalam berbagai aspek kehidupan. Jika diperhatikan, realitas kehidupan yang berkaitan dengan peningkatan peran wanita of masyarakat sangat beragam. Ada wantta-wanita yang bekerja of pabrik, di kantor, di toko, bahkan menjadi tenaga kerja di negara lain. Bidang ilmu pengetahuan pun tidak lepas dari jangkauan perempuan, terbukti banyak ilmuwan, peneliti, dokter sampai dengan profesi-profesi yang biasanya identik dengan pekerjaan laki-laki telah ditekuni oleh perempuan.

Dunia bisnis dan politik tampak semakin diminati pula oleh kaum perempuan. Hal tersebut didukung oleh hasil survey tingkat dunia mengenai perempuan dalam pembangunan (women in development) diketahui bahwa kaum perempuan mempunyai peran yang cukup besar, akan tetapi karena perempuan diperlakukan tidak adil, maka ia tidak dapat menikmati hasil sesuai dengan perannya (Salim, 1999), atau perempuan juga sering dieskploitasi dalam dunia bisnis. Kemajuan tersebut juga dijelaskan oleh Darwin dan Tukiran (2001) bahwa salah satu cermin modernisasi adalah perluasan hak perempuan sebagai manusia merdeka dan kesamaan hak yang dimiliki perempuan dalam berbagal aspek kehidupan domestik dan publik, termasuk hak polltik, hak pendidikan, hak memperoleh pekerjaan, hak kesehatan reproduksl, dan lain-lain. Perubahan tersebut temyata belum sepenuhnya mampu mengubah pandangan mengenai peran gender Ini. Tuntutan budaya terhadap peran gender masih menunjukkan ke- timpangan yang cukup tajam. Hal itu tampak pada peran gender yang tidak setara pada sebagian besar budaya di dunia.

\section{PENGERTIAN PERAN JENIS KELAMIN}

Pengertian peran jenis kelamin (sex roles) merupakan peran yang berhubungan dengan ciri-ciri jenis kelamln, sehingga karakteristik yang mencirikan sifat kewanitaan disebut sebagai feminin, dan karakteristik yang mencirikan sifat kejantanan disebut maskulin, (Taylor, dkk. 2000). Individu yang mempunyai slfat asertif dan bebas dianggap sebagal maskulin, sedangkan individu yang penuh kaslh sayang dan pengertian dianggap bersifat feminin.

Perempuan sering diharapkan berperilaku feminin, laki-laki diharapkan mempunyai sifat maskulin, sehingga melahirkan konsep peran gender yang dibentuk oleh faktor sosial budaya. Bem (Taylor, dkk2000) mengajukan karakteristik androgin untuk mempertegas bahwa kemungkinan individu baik laki-laki maupun perempuan mengkombinasikan kekuatan maskulin dan kekuatan feminin, sehingga individu dapat mengembangkan kedua sifat tersebut sesuai dengan keadaan.

\section{PENGERTIAN PERAN GENDER}

Umar (1999) menyatakan bahwa gender secara umum digunakan untuk mengidentifikasikan perbedaan antara lakilaki dan perempuan dari segi sosial budaya, sehingga gender lebih banyak berkonsentrasi kepada aspek sosial, budaya, psikologis, dan aspek non biologis lainnya. Gender berkaitan dengan persepsi terhadap kewanitaan atau kepriaan yang disebabkan oleh atribut yang diberikan masyarakat.

Peran gender (gender roles) adalah sejumlah harapan yang diinglnkan oleh 
masyarakattertentu mengenai perilaku yang sesual dengan pria dan wanita, (Feidman, 1999). Peran gender mengacu pada harapanharapan sosial tentang apa yang harus dilakukan, dipikirkan, dan dirasakan okeh seorang individu sebagai laki-lakidan perempuan. Pe ran gender d betagai tempat dan waktu tidak sama, bahkan dapat berubah seiring perubahan sosiai yang terjadi di masyarakat (Fakih dalam Mosse, 1996).

Feidman (1999) menambahkan bahwa harapan tentang perempuan dan laki-laki berbeda secara signifikan. Pria iebih dipandang sebagai individu yang mempunyai sifat seperti, kebebasan, objektivitas, dan kompetitif. Wanita cenderung dilihat sebagai individu yang mempunyal sifat seperti, kehangatan, ekspresit, kehalusan, dan kesadaran akan perasaan orang lain. Asumsi tersebut juga didukung oleh Fischer (2000) yang mengungkapkan bahwa sesuai dengan norma gender, wanita diharapkan untuk menjadi pengasuh (nurturant), menaruh perhatian terhadap orang lain, tertarik dengan hubungan interpersonai, dengan kata lain, untuk memenuhi peran sosial yang dikehendaki lingkungan, maka perempuan adalah ekspresif dan agak berorientasi pasif. Laki-laki diharapkan menjadi agen yang aktif, yang memprioritaskan tujuan impersonal, dan mampu untuk menguasai dunianya, sehingga lebih menekankan rasionalitasnya.

\section{KONSEP ANDROGINI}

Pandangan mengenai peran gender yang telah disosialisasikan kepada anakanak menyebabkan intemalisasi nilai-nilai gender terhadap anak-anak tersebut, sehingga anak-anak akan mengembangkan skema gender. Bem mengajukan konsep androgini untuk mengurangi kemungkinan anak-anak akan mengembangkan skema gender, yaitu kerangka kognitif yang diatur dan diarahkan oleh pemahaman anak terhadap informasi yang relevan dengan gender (Feidman, 1999). Individu yang androgin mengkombinasikan karakteristik dari kedua jenis kelamin. Laki-laki yang androgin tidak hanya mengembangkan agresivitas dan kekuatan yang dipandang sebagai karakter maskuiin oleh masyarakat, tetapi juga dapat mengembangkan karakter feminin seperti kehailusan ketika perilaku itu diperlukan. Perempuan yang androgin tidak hanya mengembangkan emosi dan empati yang dianggap sebagai karakterfeminin oleh masyarakat, tetapi juga dapat mengembangkan rasionaltas dan kemandirian yang selama ini dipandang sebagai karaktermaskulin.

Karakteristik androgin tidek bermaksud untuk mengaburkan identitas seksual seseorang, tetapi lebih bertujuan untuk mengoptimalkan potensi-potensi positif yang dimiliki oleh perempuan dan lakj-laki. Seperti halnya dalam proses membentuk keptibadian, diharapkan individu mampu mengembangkan sifat maskulin dan feminin sesual dengan situasi, tanpa membedabedakan jenis kelamin. Pengembangan sifat androgin pada individu memungkinkan perkembangan kepribadian manusia menjadi optimal.

\section{PERAN GENDER DAN BUDAYA}

Sejak peristiwa kelahiran, seorang bayi sudah diberi labei oleh kebanyakan orang tua dengan selimut biru untuk laki-laki, selimut merah muda untuk perempuan. Harapan yang sesuai dengan gender terus berkembang, misalnya tampak ketika perempuan dan laki-laki diberi permainan yang berbeda. Seorang ayah lebih suka bermain secara keras (roughly) dengan bayl laki-laki dibandingkan dengan bayi perempuan. Remaja perempuan lebin dituntut untuk menjaga kehormatan dibandingkan dengan remaja laki-laki yang cenderung lebih dibebaskan dalam per- 
gaulan. Orang dewasa sering memperlakukan anak-anak secara berbeda berdasarkan gender. Sosialisasi peran gender terhadap anak ternyata tidak hanya dilakukan oleh orang tua tetapi masyarakat memberi pesan secara jelas kepada anak-anak sejalan dengan pertumbuhan mereka. Buku bacaan anak-anak secara tradisional digambarkan bahwa anak perempuan dberi stereotip peran mengasuh (nurtutant roles), sedangkan anak laki-laki diberi peran yang beorientasi fisik dan tindakan (action-oriented roles), (McDonald, 1989, Crabb\& Pristash, 1992,dalam Feldman, 1999). Televisl pun juga turut melakukan sosialisai peran gender, misalnya perempuan sering digambarkan sebagai sosok yang le mah dalam sinetron-sinetron.

Keyakinan yang telah tersebar luas dalam masyarakat berkisar soal laki-laki dan perempuan (stereotip gender) telah banyak dikaji di masyarakat Barat. William \& Best (dalam Malsumoto, 1996) melaporkan hasil penelitiannya yang menunjukkan bahwa ada suatu perbedaan dalam pandangan mengenai laki-laki dan perempuan tampak serupa di semua negara. Tabel di bawah ini memberikan 100 aitem dari pancultural adjective checklist yang dllaporkan oleh William

The 100 Items of the Pancultural Adjective Checklist

\begin{tabular}{|c|c|}
\hline $\begin{array}{l}\text { Active (aktlf) } \\
\text { Adventurous (pemberanl) } \\
\text { Aggressive (agresif) } \\
\text { Arrogant (sombong) } \\
\text { Autocratic (otokralli } \\
\text { Bossy (suka meraja) } \\
\text { Capable (mampu) } \\
\text { Conceited (angkuh) } \\
\text { Confident (yakin) } \\
\text { Courageous (berani) } \\
\text { Cruel (kejam) } \\
\text { Cynical (suka mengejek) } \\
\text { Determined (menentukan) } \\
\text { Disordery (tidak leratur) } \\
\text { Enterprisirg (mau berusaha) } \\
\text { Greedy (rak us) }\end{array}$ & $\begin{array}{l}\text { Hardheaded (keras kepala) } \\
\text { Humorous (suka humori } \\
\text { Indifferent (acuh tak acuh) } \\
\text { Individualist ic (individualistik) } \\
\text { Inilialive (inisiatif) } \\
\text { interests wide (Icetertarikan luas) } \\
\text { Inventive (berdaya clpta) } \\
\text { Lary (malas) } \\
\text { Loud (bersuara keras) } \\
\text { Obnoxious (mertiengkeikan) } \\
\text { Opintionated (berpendirian keras) } \\
\text { Opportunistic (oportunistik) } \\
\text { Pleasure seekng (mencart kesenangan) } \\
\text { Precise (tepat) } \\
\text { Proggressive (progresif) } \\
\text { Rational (rasional) }\end{array}$ \\
\hline
\end{tabular}

Female-Associated

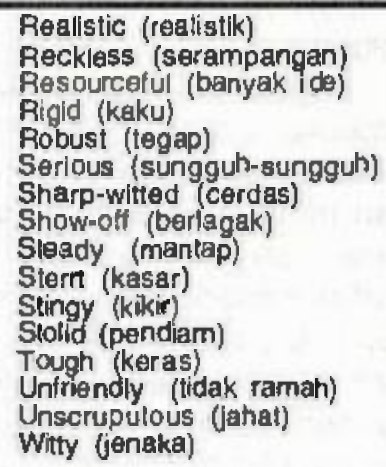

Affected (dipengaruhi perasaan) Foolish (bodoh)

Affectionate (penulh kasih sayang) Forgiving (mudah memaafkan)

Appreclate (menghargal)

Cautious ('jerhat $J-h a l_{1}$ )

Change acile (berubah-ubah)

Charming (luwes)

Complaining (mengeluh)

Contused (membingungkan)

Curious (ingln tahu)

Dependent (tergantung)

Dreamy (melamun)

Emotional (emosional)

Excltable (mudah targugah)

Faull-finding (bawel/cerewelt)

Feartul (takut:)

Fickle (tidak totap)
Frivolous (sembrono)

Fussy (rewel)

Gentle (iemah lembut)

Ima ginative (imalinatif)

Kin d (baik hati)

Miid (halus)

Modest (rendah hati)

Nervous (cemas)

Patient (sabar)

Pleasant (menyenangkan)

Prudish (sangat sopan)

Self-pitying (kasihan pada dirinya)

Sensitive (sensitif)

Sexy (seksi)
Shy (malu)

Solthearted (lembut hati)

Sophisticated (plnter dan nilimet)

Submissivo (petuh)

Suggestible (mudah tersugasti)

Talkatlve (suka berblcara)

Timld (takut/malu)

Toughy (perasa)

Unambitious (tidak berambisi)

Unintelligent (tidak cerdas)

Unstable (tldak stabll)

Warm (hangat)

Woak (lemah)

Worying (khawatir)

Understanding (pengertian)

Superstitious (suka bertakhayul) 


\section{\& Best.}

Hasil penelitian mengenal perbedaan gender antara orang Afrika Amerika dan Eropa Amerika, menunjukkan bahwa orang laki-laki Afrika Amerika lebih mungkin untuk hidup d bawah garis kemiskinan, meninggal pada usia lebih muda, menghasilkan uang lebih sedikit, masuk penjara, dan terdakwa dalam kejahatan, dibandingkan dengan lakllaki Eropa Amerika (Matsumoto, 1996).

Banyak keluarga Asia Amerika mengembangkan peran gendertradisional yang berhubungan dengan laki-laki dan perempuan dari budaya asli mereka. Perempuan Asia sering diharapkan memikul beban berat tugas-tugas domestik, mengasuh anak, dan harus menjadi menantu yang baik. Laki-laki Asia Amerika sering tampak mandiri, tidak emosional, dan otoritatifi, khususnya berkaitan dengan masalah keluarga.

Seperti halnya peran gender Asia Amerika, peran tradislonal perempuan Meksiko menyediakan diri untuk anak-anak dan memperhatikan rumah. Di sisi lain peran laki-laki Meksiko Amerika secara tradisional didoktrin dengan harapan kuat sebagai pemberi nafkah bagi keluarga. Perbedaan-perbedaan ini berkaitan dengan konsep machismo. Konsep ini meliputi harapan-harapan peran gender lakl-laki, sebagal tidak emosional, kuat, otoritatif, agresif, dan maskulln. Meskipun begitu penelitian akhir-akhir ini menunjukkan bahwa perbedaan gender pria dan wanita Meksiko Amerika juga mengalaml penurunan. Wanita Meksiko Amerika mengalami peningkatan pengambilan keputusan dalam keluarga. sebagaimana turut berperan langsung sebagai pencari nafkah dengan bekerja di Iuar rumah. Sementara remaja laki-laki masih lebih diberi kebebasan di luar rumah dari pada perempuan, jadi perbedaan gender mengalami penurunan dalam keluarga Meksiko Amerika kontemporer. Jadi perbedaan peran gender untuk bangsa Amerika tampak tergantung pada model patriarkai atau matriarkal.

Hasil penelitian lain diungkapkan oleh Mitina \& Petrenko (2001) di antaranya menyimpulkan bahwa kebahagiaan wanita Rusia dapat diraih sepenuhnya dalam keluarga. Wanita yang bahagia adalah seseorang yang mempunyai kesempatan untuk mencurahkan hldupnya kepada keluarganya, menjadi bu rumah tangga, dan berurusan dengan jahit-menjahit dan memasak. Sedangkan kebahagiaan wanita Amerika dapat diraih melalui realisasi diri profesionai. Lapangan pekerjaan yang paling memuaskan wanita Amerika adalah bldang obat-obatan, media massa, atau mempunyai usaha sendiri.

Urajan d atas dapat disimpulkan bahwa perbedaan peran gender antara laki-laki dan perempuan ada dalam semua budaya. Banyak stereotip yang muncul secara universal mengenai pebedaan gender secara lintas budaya seperti agresivitas, kekuatan, dan kurang emosional pada laki-laki, serta kelemahan, penerimaan, dan emosionalitas pada perempuan.

\section{PERAN GENDER MASYARAKAT JAWA}

Sistem patriarkhis masyarakat Jawa pada abad 18 , telah molahirkan ungkapanungkapan (yang sering kali masih terdengar hingga sekarang) yang dianggap menyiratkan inferioritas wanitaJawa (Fananie, 2000). Ungkapan-ungkapan seperti kanca wingking, swarga nunut neraka katut, wanita hanya mengurus dapur, wanita hanya bergantung pada suami, menegaskan bahwa wanita Jawa tampak menduduki struktur bawah. Kuatnya konsepsi tersebut dalam budaya Jawa, menimbulkan perlakuan-perlakuan yang dianggap membatasi ruang gerak wanita, seperti halnya konsep pingitan, yaitu melarang wanita untuk bebas 
beraktivitas. Dengan kata lain wanita harus nrimo, pasrah, halus, sabar, setia, dan berbakti.

Hal tersebut juga digambarkan oleh Darwin dan Tukiran (2007), bahwa sosok lelaki ideal dalam imajinasi orang Jawa adalah lelananging jagadyang sakti, tampan, dan banyak istri, seperti Arjuna, tokoh Pandawa dalam pewayangan, yang selalu menang di setiap medan perang, dan selalu memenangkan hati setiap dewi. Lelaki ideal dalam imajinasi orang Jawa adalah memiliki benggol (uang) dan bonggol (kejantanan seksual). Posisi perempuan adalah milik laki-laki, sejajardengan bondo (harta), griyo (istana), turonggo (kendaraan), kukilo (burung atau binatang piaraan), dan pusoko (senjata, kesaktian). Penguasaan terhadap perempuan (wanito) merupakan simbol kejantanan seorang lelaki, sebaliknya ketundukan, ketergantungan, dan kepasrahan perempuan kepada lakilakj adalah gambaran kemuliaan hati seorang perempuan Jawa. Gambaran tersebut meskipun dikatakan sebagai imajinasi, tetapi sering dijadikan falsafah bagi orang Jawa dalam memandang perempuan,

Hanum mengungkapkan Kenyataan bahwa sebagian besar wanita menjadi tergantung pada laki-laki, bukan saja secara ekonomis, tetapi juga secara psikologis (Milla, 1999). Banyak wanita kemudian percaya bahwa perkawinan merupakan tempat satu-satunya bagi mereka untuk menyelamatkan hidupnya, kemudian perkawinan dapat memecahkan masalah ketergantungan ekonomis dan psikologis. Meskipun dalam masyarakat terjadi perubahan pandangan tentang peran perempuan dan laki-laki secara bertahap, namun demikian wanita tetap dituntut menyediakan waktu untuk mengurus rumah tangga, ataupun bertanggung jawab pada sektor domestik.

Ada perbedaan peran gender yang besar pada masyarakat Jawa, bila dilihat dari sejarah, meskipun telah terjadi pergeseran jaman, pengaruh budaya Barat masuk, pendidikan mulai meningkat. Hal itu didukung oleh beberapa hasil penelitian bertema gender di Jawa yang tel ah dilakukan beberapa tahun terakhir.

Penelitian yang dilakukan oleh Kartodirdjo dan Tukiran (dalam Darwin dan Tukiran, 2001) telah menggali kebudayaan priayi Surakarta. Laki-laki priayi dipandang sebagai pengayom (pelindung dalam arti luas) bagi perempuan dan keluarga priayi sehingga dominasinya terhadap perempuan dan keluarga sangat kuat. Perempuan priayi dituntut untuk menjadi "perempuan ideal" dalam keluarga priayi, yaitu bertingkah laku sopan, memelihara kesehatan dan kecantikan tubuh dengan min um jamu tradisional, mengenakan busana Jawa yang menarik gairah suami, serta mempelajari pengetahuan seksual dari emban. Hasil penelitian ini menyebutkan bahwa dampak dari pendidikan modern yang dicapai generasi muda priayl adalah dominasi lakilaki terhadap perempuan mulai mengendor dalam sistem budaya priayl. Perempuan priayl dapat mengambii keputusankeputusan yang menyangkut kehidupan keluarganya. Mereka mulai menghargai pentingnya bekerja, baik dalam instansi pemerintahan maupun swasta. Penelitian ini juga menyimpulkan bahwa dinamika kebudayaan priayi yang berkembang dalam era perubahan budaya kota modem, seperti kota Surakarta, menunjukkan adanya sebagian unsur-unsur kebudayaan priayi yang tenggelam, dan ada sebagian unsurunsur yang masih mempunyai eksistensi (seperti bahasa, etiket, seni, dan pengetahuantentangramuan jamu tradisionalJawa).

Penelitian yang dilakukan oleh Marpinjun $S$ dkk. yang tergabung dalam LSPPA (Lembaga Studi dan Pengembangan Perempuar dan Anak) menupakan representasi 
dari masyarakat Jawa yang bukan priayi, yaitu desa Limbangan, sebelah tenggara kota Klaten (Salim, 1999). Penduduk desa ini baik perempuan maupun laki-laki, tidak sedikit yang merantau ke Solo atau Yogyakarta untuk melanjutkan sekolah yang lebih tinggi dan dianggap lebih baik mutunya. Kenyataan tersebut menggambarkan bahwa masyarakat desa ini sudah menyadari pentingnya pendidikan tinggi. Hasil penelitian ini mendapatkan beberapa pandangan mengenai peran gender pada masyarakat Jawa, yaitu:

1. Arti dan nilai anakmenurutjenis kelamin.

Anak laki-kaki cenderung mempunyai arti yang berhubungan dengan martabet, perlindungan, dan tumpuan harapan keluarga d masa depan, sehingga anak laki-laki mempunyai tanggung jawab yang lebih besar. Anak perempuan mempunyai arti yang berhubungan dengan kepraktisan, dalam arti kehadirannya bermanfaat untuk memperlancar kegiatan beres-beres urusan rumah tangga, sedangkan anak-laki-laki dianggap tabu melakukan tugas-tugas rumah tangga. Hal tersebut seperti diungkapkan kebanyakan para lbu, bahwa keuntungan mempunyai anak perempuan adalah mereka dapat membantu ibunya membereskan pekerjaan rumah. Dahulu ada anggapan bahwa perempuan tidak perlu sekolah tinggitinggi, karena pada akhirnya akan ke dapur juga. Jadi di satu sisi masyarakat mengakui bahwa anak perempuan mempunyai potensi membawa manfaat layaknya anak laki-laki, tetapi di sisi lain masyarakat belum percaya sepenuhnya menyerahkan beban martabat keluarga d pundak anak perempuan. Seperti sering diungkapkan orang tua: ${ }^{m}$ Kalau anak perempuannya menikah akan dibawa oleh suaminya."

2 Pengenalan norma gender pada masa kecil

Pengenalan norma gender dimulai dari pemberian nama pada anaknya. Namanama feminin diperuntukkan bagi anak perempuan dan nama-nama maskulin untuk anak laki-laki. Pembiasaan yang berkaitan dengan jenis kelamin berlangsung seiring dengan bertambahnya umur. Misalnya anak perempuan jangan suka ngeyel, anak laki-laki tidak boleh cengeng. Pemberian permainan pun harus sesuai dengan jenis kelamin. Orang tua gelisah jika anak lakilakinya bermain boneka, khawatir anaknya seperti perempuan, banci, dan sebagainya. Mereka juga percaya bahwa anak laki-laki dan perempuan mempunyai pembawaan sifat yang berbeda: anak laki-laki sulit diatur dan anak perempuan lebih mudah diatur, serta memahami keinginan orang tua.

3. Persoalan pergaulan, seksualitas, dan cita-cita di kalangan remaja.

Masyarakat (orang tua) biasanya memberikan larangan yang lebih banyak bagi remaja perempuan, seperti mengingatkan mereka untuk menjaga kehormatan, tidak boleh keluar rumah sendirian pada malam hari. Sedangkan larangan untuk anak laki-laki tidak seketat anak perempuan. Perempuan sekarang nampaknya sudah tidak berbeda dalam aspirasinya, yaitu mereka jug a mempunyai motivasi yang kuat untuk bekerja di luar rumah Namun, noma peran ganda wanta juga sudah terintemalisasi sejak remaja.

4. Pembagian peran dalam rumah tangga Suami berkewajban menjadi kepala keluarga, yaitu menafkahi dan melindungi keluarganya, tetapi tidak wajib membantu ugas istri d rumah. Isti wajib 
menjadi ibu rumah tangga, tetapi tidak wajib bekerja atau berkarir. Jadi citra ideal suami adalah sebagai kepala keluarga yang bertanggung jawab, sedangkan istri adalah pemeran ganda.

Dari uraian di atas dapat dikatakan bahwa anak akan belajar mengenai perikaku yang berkaitan dengan jenis kelamin sesuai stereotip yang berlaku di masyarakat. Penanaman peran genderpada masyarakat Jawa berlangsung terus menerus sejak lahir sampai dengan menjadi orang tua.

Hasil-hasil penelitian di atas menggambarkan bahwa pergeseran pandangan mengenai peran gender sudah ada, seperti dalam masyarakat priayi maupun masyarakat desa yang sudah banyak menerima pendidikan, tetapi tidak menjadikan kedudukan perempuan menjadi seimbang terhadap laki-laki. Hal ini terbukti dari hasil penelitian di atas bahwa masih ada ada subordinasi laki-laki terhadap perempuan pada masyarakat desa maupun priayi. Penelitian-penelitian di atas memberikan gambaran kepada kita bahwa faktor sosial dan budaya Jawa telah mengakar, sehingga pandangan orang terhadap peran gender tidak mudah untuk berubah. Hal itu mementukan pemikiran lebih lanjut untuk mengurangi ketimpangan peran gender di masyarakat dengan pemahaman terhadap budaya.

\section{KESIMPULAN}

Perbedaan peran gender ada dalam setiap budaya, tetapi masing-masing budaya mempunyai intensitas yang berbeda-beda, demikian pula pada budaya Jawa yang menjadi sorotan dalam tulisan ini. Perubahan sosial ternyata belum sepenuhnya membawa pandangan yang setara terhadap peran gender antara perempuan dan lakilaki. Hal tersebut menimbulkan permasalahan bias gender di masyarakat, sehingga sering merugikan laki-laki maupun perempuan. Konsep androgini yang diungkapkan oleh Bem pertu dikembangkan, yaitu sebaiknya perempuan dan laki-laki mengembangkan sifat-sifat maskulin dan feminin secara seimbang, dengan memahami budaya Jawa, sehingga masingmasing individu dapat mengembangkan kepribadian secara optimal.

\section{DAFTAR PUSTAKA}

Chang, L. 1999. Gender Role Egalitarian Attitudes in Beijing, Hongkong, Florida, and Michigan. Jou ma / of Cross-Cultural Psychology, 30: 7,2,2-732.

Darwin, M. dan Tukiran, (editor). 2001. Menggugat Budaya Patriarkhi. Yogyakarta: Pusat Penelitian Kependudukan Universitas Gadjah Mada bekerja sama dengan Ford Foundation.

Ervita, 2000. Sikap terhadap Kemitrasejajaran Ditinjau dari Peran Jenis dan Jenis Kelamin. Skripsi (Tidak Diterbitkan). Yogyakarta: Fakultas Psikologi UII.

Fananie, Z 2000. Restrukturisasi Budaya Jawa. Perspektif KGPAA MN i. Surakarta: Muhammadiyah University Press.

Feldman, R. S. 1999. Understanding Psychology (Fifth edition). United State of America: The McGraw-Hill Companies, Inc.

Fischer, A. H. 2000. Gender and Emotion. Social Psychological Perspectives. United Kingdom: Cambridge University Press.

Matsumoto, D.1996. CuthreandPsychology. Brooks/Cole Publishing Company.

Milla, M. N. 1999. Generativitas (Keberkembangan) Wanita Jawa yang Tidak 
Menikah pada Masa Tengah Baya: Motivasi, Perhatian, dan Narasi. Tesis. Yogyakarta: Universitas Gadjah Mada.

Mitina, O. V. \& Petrenko, V. F. 2001. A Cross - Culturai Study of Stereotypes of Female Behavior. Russian Social Science Review, 42: 60-92.

Mosse, J.C, 1996. Gender dan Pembangunan. (Half The World, Half $A$ Chance An introduction to Gender and Development). Diterjemahkan ke dalam bahasa Indonesia oleh Hartian Slawati. Yogyakarta: Pustaka Pelajar.
Munro, D., Schumaker, J. F, Carr, S. C. 1997. Motivalion and Culture. New York \& London: Routledge.

Salim, H. (editor), 1999. Menjadi Perempuan. Yogyakarta: Pustaka Pelajar bekerja sama dengan Lembaga Studi dan Pengembangan Perempuan dan Anak dan Ford Foundation.

Taylor, S. E., Peplau, L.A., \& Sears, D. O. 2000. Social Psychology (Tenth Edition). New Jersey: Prentice Hall internationai, Inc.

Umar, N. (1999). Argumen Kesetaraan Gender. Perspektif Al Quran. Jakarta: Paramadina. 